\title{
Originals
}

\section{Increased platelet thromboxane receptor sensitivity in diabetic patients with proliferative retinopathy}

\author{
A. Collierr', P. Tymkewycz ${ }^{2}$, R. Armstrong'2, R.J. Young ${ }^{1}$, R. L. Jones ${ }^{2}$ and B. F. Clarke ${ }^{1}$ \\ ' Diabetic and Dietetic Department, Royal Infirmary and ${ }^{2}$ Department of Pharmacology, University of Edinburgh, Edinburgh, UK
}

\begin{abstract}
Summary. Platelet aggregation to collagen in 12 Type 1 (insulin-dependent) diabetic patients with background retinopathy and 12 Type 1 diabetic patients with proliferative retinopathy was compared with an age- and sex-matched control group. An analogue of prostaglandin $\mathrm{H}_{2}, 11,9$ epoxymethano-prostaglandin $\mathbf{H}_{2}$, which directly stimulates thromboxane receptors, and EP 092, which is a competitive thromboxane $\mathrm{A}_{2}$ receptor antagonist, were used to investigate changes at platelet thromboxane receptor level in these groups. The concentration of collagen $\left(\mathrm{EC}_{50}\right)$ required to give $50 \%$ of maximum
\end{abstract}

aggregation did not differ between the two diabetic groups and the control group. However, platelets from the proliferative retinopathy group were significantly more sensitive to the thromboxane mimetic (11,9 epoxymethano-prostaglandin $\mathrm{H}_{2}$ ) $(p<0.005)$ than the background retinopathy and control groups. This change may be a factor in the development of proliferative retinopathy.

Key words. Platelets, thromboxane sensitivity, cAMP, proliferative retinopathy.
Previous studies in diabetes mellitus have demonstrated abnormalities of platelet function such as exaggerated response to aggregating agents [1] and refractoriness to inhibiting prostaglandins (PG) $[2,3]$. Hyperaggregation is reported to be associated with poor glycaemic control [4], increasing age [5], and the presence of micro- and macrovascular changes $[6,7]$. A number of circulatory substances relevant to coagulation, including lipids [8], fibrinogen [9] and von Willebrand factor [10] have also been reported as abnormal in diabetic patients. However, particularly in the presence of vascular complications [11, 12,13], the results have been inconsistent, perhaps because of the diverse methods used and the failure to obtain homogenous patient groups.

Where a possible mechanism for enhanced platelet aggregation has been investigated, the most consistent finding has been the increased production of aggregation-induced thromboxane $\mathrm{A}_{2}\left(\mathrm{TXA}_{2}\right)[14,15]$. TXA which is the predominant metabolite of platelet arachidonic acid (AA), is a powerful platelet aggregator and vasoconstrictor $[16,17]$. Most studies have employed AA itself or an agent such as collagen, which releases endogenous platelet $\mathrm{AA}$, to demonstrate enhanced platelet aggregation. Since the production of $\mathrm{TXA}_{2}$ is known to be increased, it cannot be determined from these studies $[11,12]$ whether improved receptor coupling or an increase in the number of thromboxane receptors may also contribute to this increased sensitivity.
The aims of this study were to confirm platelet hyperaggregability to collagen and to investigate the changes at receptor level in platelets from diabetic patients with established microangiopathy using an analogue of $\mathrm{PGH}_{2}, 11,9$ epoxymethano $\mathrm{PGH}_{2}(11,9-\mathrm{em}$ $\mathrm{PGH}_{2}$ ), which directly stimulates thromboxane receptors $[18,19]$, plus a competitive thromboxane receptor antagonist (EP 092) [20]. Young insulin-dependent diabetic patients who had background and proliferative retinopathy as well as a non-diabetic control group were selected in order to investigate the possible relationship between platelet function and susceptibility to proliferative retinopathy.

\section{Subjects and methods}

The patients studied were 24 Type 1 (insulin-dependent) diabetic patients, 12 with background and 12 with proliferative retinopathy. The patients were compared with 12 non-diabetic healthy volunteers. The three groups were comparable for age and sex, and the diabetic groups were matched for duration of diabetes. There was no significant difference between the two diabetic groups in blood glucose, $\mathrm{HbA}_{1}$ or platelet counts at the time of the study. (Table 1). Classification of retinopathy was based on ophthalmoscopic and fluorescein angiographic appearances in all patients. In the background retinopathy group three patients had scattered microaneurysms and haemorrhages, seven patients had hard exudative changes and two patients had ischaemic preproliferative changes. None of the diabetic subjects were taking any medication other than insulin, all of the patients were 
Table 1. Average age, duration of diabetes, plasma glucose, $\mathrm{HbA}_{1}$ and platelet counts in control and diabetic retinopathy groups

\begin{tabular}{lllllcc}
\hline Group & $\begin{array}{l}\text { Number of } \\
\text { Subjects }\end{array}$ & $\begin{array}{l}\text { Average age } \\
(\mathrm{yrs})\end{array}$ & $\begin{array}{l}\text { Duration of } \\
\text { diabetes }(\mathrm{yrs})\end{array}$ & $\begin{array}{l}\text { Plasma glucose } \\
(\mathrm{mmol} / \mathrm{l})\end{array}$ & $\begin{array}{c}\text { HbA }(\%) \\
\text { Platelet } \\
\text { count }\left(\times 10^{9} / 1\right)\end{array}$ \\
\hline Control & $12(6 \mathrm{~F}, 6 \mathrm{M})$ & $26.7 \pm 1.3$ & - & $4.6 \pm 0.3$ & $7.6 \pm 0.3$ & $274 \pm 11$ \\
$\begin{array}{l}\text { Background } \\
\text { Retinopathy }\end{array}$ & $12(6 \mathrm{~F}, 6 \mathrm{M})$ & $27.6 \pm 0.9$ & $15.2 \pm 1.1$ & $10.5 \pm 1.0$ & $11.8 \pm 0.7$ & $257 \pm 16$ \\
$\begin{array}{l}\text { Proliferative } \\
\text { Retinopathy }\end{array}$ & $12(6 \mathrm{~F}, 6 \mathrm{M})^{\mathrm{a}}$ & $27.0 \pm 1.5^{\mathrm{a}}$ & $14.6 \pm 1.4^{\mathrm{b}}$ & $11.6 \pm 1.7^{\mathrm{b}}$ & $12.6 \pm 0.7^{\mathrm{b}}$ & $245 \pm 12^{\mathrm{b}}$ \\
\end{tabular}

Results expressed as mean \pm SEM. a NS between the three groups; ${ }^{b}$ NS between the diabetic groups

Table 2. Results of aggregation $\mathrm{EC}_{50}$ and dose ratio for collagen and $11,9 \mathrm{emPGH}$ alone and in the presence of $\mathrm{EP} 092(0.25 \mu \mathrm{mol} / \mathrm{l})$ and Froben $(10 \mu \mathrm{mol} / 1)$. Results expressed as mean $\pm \mathrm{SEM}$

\begin{tabular}{|c|c|c|c|c|c|c|c|c|c|c|}
\hline Group & $\begin{array}{l}\text { Collagen } \\
\mathrm{EC}_{5}{ }^{0} \\
(\mu \mathrm{g} / \mathrm{ml})\end{array}$ & $\begin{array}{l}\text { Collagen } \\
+\mathrm{EP} 092 \\
\mathrm{EC}_{50} \\
(\mu \mathrm{g} / \mathrm{ml})\end{array}$ & $\begin{array}{l}\text { Dose } \\
\text { Ratio }\end{array}$ & $\begin{array}{l}\text { Collagen } \\
+ \text { Froben } \\
\mathrm{EC}_{50} \\
(\mu \mathrm{g} / \mathrm{ml})\end{array}$ & $\begin{array}{l}\text { Dose } \\
\text { Ratio }\end{array}$ & $\begin{array}{l}11,9 \text { emPGH } \\
\mathrm{EC}_{50} \\
(\mathrm{ng} / \mathrm{ml})\end{array}$ & $\begin{array}{l}11,9 \mathrm{emPGH}_{2} \\
+\mathrm{EP} 092 \\
\mathrm{EC}_{50} \\
(\mathrm{ng} / \mathrm{ml})\end{array}$ & $\begin{array}{l}\text { Dose } \\
\text { Ratio }\end{array}$ & $\begin{array}{l}11,9 \text { emPGH } \\
+ \text { Froben } \\
\mathrm{EC}_{50} \\
(\mathrm{ng} / \mathrm{ml})\end{array}$ & $\begin{array}{l}\text { Dose } \\
\text { Ratio }\end{array}$ \\
\hline Control & $0.8 \pm 0.1$ & $1.9 \pm 0.3$ & $2.4 \pm 0.2$ & $8.3 \pm 1.9$ & $9.8 \pm 2.0$ & $99.4 \pm 10.0$ & $115.3 \pm 5.2$ & $1.7 \pm 0.1$ & $124.7 \pm 9.4$ & $1.31 \pm 0.1$ \\
\hline $\begin{array}{l}\text { Background } \\
\text { retinopathy }\end{array}$ & $0.74 \pm 0.1$ & $1.8 \pm 0.3$ & $2.7 \pm 0.5$ & $6.6 \pm 1.6$ & $10.8 \pm 3.4$ & $85.4 \pm 11.5$ & $193.8 \pm 28.4$ & $2.6 \pm 0.6$ & $120 \pm 12.9$ & $1.51 \pm 0.4$ \\
\hline $\begin{array}{l}\text { Proliferative } \\
\text { retinopathy }\end{array}$ & $1.1 \pm 0.2$ & $1.9 \pm 0.4$ & $1.9 \pm 0.2$ & $4.9 \pm 0.7$ & $5.0 \pm 0.5$ & $63.5 \pm 6.6$ & $176.0 \pm 20.2$ & $3.15 \pm 0.6$ & $100.4 \pm 8.8$ & $1.62 \pm 0.1$ \\
\hline Significance & NS & NS & NS & NS & NS & $p<0.005$ & NS & $p<0.005$ & NS & NS \\
\hline
\end{tabular}

$p<0.005$, significant difference between proliferative retinopathy group and background retinopathy group

clinically free of nephropathy (urine Albustix negative and plasma creatinine less than $150 \mu \mathrm{mol} / \mathrm{l}$ ) and all had easily palpable peripheral pulses.

Blood $(100 \mathrm{ml})$ was collected between 08.00 and 09.00 hours from fasted diabetic patients and control subjects into plastic centrifuge tubes containing acid-citrate dextrose (ACD) anticoagulant and centrifuged at $120 \mathrm{~g}$ for $20 \mathrm{~min}$. The platelet-rich plasma (PRP) was then pre-incubated with $\left[{ }^{14} \mathrm{C}\right] 5$-hydroxytryptamine (final concentration $1 \mu \mathrm{g} / \mathrm{ml}$ ) for $30 \mathrm{~min}$ at $37^{\circ} \mathrm{C}$. Platelet aggregation was studied using the photometric method of Born [21, 22]. Dose response curves for aggregation induced by collagen and $11,9-\mathrm{em} \mathrm{PGH}_{2}$ were determined both in the presence and absence of a cyclooxygenase inhibitor, Froben $(10 \mu \mathrm{mol} / \mathrm{l})$, which eliminated the production of endogenous $\mathrm{TXA}_{2}$ and allowed assessment of aggregation in the absence of the secondary aggregation wave. In addition, we measured the shift in dose-response curve for aggregation using a fixed concentration of a competitive $\mathrm{TXA}_{2}$ receptor antagonist EP $092(0.25 \mu \mathrm{mol} / 1)$. Each aliquot was warmed to $37^{\circ} \mathrm{C}$ for $2 \mathrm{~min}$ prior to the addition of the aggregating agents. If used, Froben or EP 092 were added at time zero, 2 min before the addition of the aggregating agent.

Release of platelet dense granule constituents (5HT, ADP) were measured using the radiolabelled isotope $\left[{ }^{14} \mathrm{C}\right] 5$-hydroxytryptamine prelabelling technique [22]. Basal platelet cAMP and the rise in cAMP induced by $\mathrm{PGE}_{1}(0.2 \mu \mathrm{mol} / \mathrm{l})$ were measured by a protein binding assay $[22,23]$.

The glycosylated haemoglobin assay was carried out by electrophoresis using commercially available agar plates (Corning Medical, Halstead, UK) as described by Read et al. [24], the normal range being $6-8 \%$.

11,9-em $\mathrm{PGH}_{2}$ and $\mathrm{PGE}_{1}$ were purchased from Upjohn, Kalamazoo, Mi, USA. Collagen was obtained from Diamed Diagnostics Ltd, Liverpool, England. EP 092 was synthesised in the laboratory of the Department of Pharmacology, University of Edinburgh. Flurbiprofen (Froben) was a gift from Boots Pharmaceuticals Ltd, Nottingham, England. $\left[{ }^{14} \mathrm{C}\right] 5$-hydroxytryptamine was purchased from Amersham, UK. All of the solutions were free of ethanol and all subsequent dilutions were made up in $0.9 \%$ saline.

\section{Statistical analysis}

Statistical analysis of the dose ratios was by Kruskal-Wallis one-way analysis of variance by ranks. Comparison between the groups for the cAMP results was by independent Student's t-test.

\section{Results}

There was no difference in the concentration of collagen $\left(\mathrm{EC}_{50}\right)$ required to give $50 \%$ of the maximum aggregation wave between the two diabetic groups and the control group (Table 2). Similarly, the thromboxane receptor antagonist EP092 shifted all three curves to a similar extent, as shown by the new $\mathrm{EC}_{50}$ values in the presence of EP 092, and by the dose ratios (DR) $\left(\mathrm{DR}=\mathrm{EC}_{50}\right.$ in the presence of $\mathrm{EP} 092 / \mathrm{EC}_{50}$ collagen alone). The cyclooxygenase inhibitor Froben produced a more marked shift of the control aggregation curves than observed with EP 092. Froben appeared to be slightly less effective in the proliferative retinopathy group, but this was not statistically significant.

There was, however, a significant difference between the three groups in the concentration of $11,9-\mathrm{em}$ $\mathrm{PGH}_{2}$ required to induce a $50 \%$ aggregation response. Less 11,9 -em $\mathrm{PGH}_{2}$ was required for the proliferative retinopathy group than for either the control or retinopathy groups $(p<0.005)$. Furthermore, EP 092 produced a significantly larger shift in the aggregation curve in the proliferative retinopathy group as judged by the dose 
Table 3. Results of platelet release reaction in control and diabetic retinopathy groups due to collagen $(2 \mu \mathrm{g} / \mathrm{ml}) \mathrm{and}(250 \mathrm{ng} / \mathrm{ml}) 11,9 \mathrm{emPGH} / 2$ alone and in the presence of EP $092(0.25 \mu \mathrm{mol} / 1)$ and Froben $(10 \mu \mathrm{mol} / \mathrm{l})$

\begin{tabular}{|c|c|c|c|c|c|c|}
\hline Group & Collagen & $\begin{array}{l}\text { Collagen } \\
+ \text { EP } 092\end{array}$ & $\begin{array}{l}\text { Collagen } \\
+ \text { Froben }\end{array}$ & $11,9 \mathrm{emPGH}_{2}$ & $\begin{array}{l}11,9 \mathrm{emPGH}_{2} \\
+ \text { EP } 092\end{array}$ & $\begin{array}{l}11,9 \mathrm{emPGH}_{2} \\
\text { + Froben }\end{array}$ \\
\hline Control & $58.8 \pm 2.2$ & $41.1 \pm 3.6$ & $19.8 \pm 1.1$ & $34.9 \pm 1.0$ & $30.9 \pm 1.4$ & $32.7 \pm 1.3$ \\
\hline $\begin{array}{l}\text { Proliferative } \\
\text { retinopathy }\end{array}$ & $55.3 \pm 5.7$ & $30.7 \pm 4.1$ & $18.4 \pm 2.4$ & $32.8 \pm 2.4$ & $28.7 \pm 3.4$ & $30.1 \pm 1.7$ \\
\hline
\end{tabular}

Results expressed as \% total $\left[{ }^{14} \mathrm{C}\right]-5$-HT released $/\left[{ }^{14} \mathrm{Cl}-5-\mathrm{HT}\right.$ taken up by platelets at pre-incubation and given as mean \pm SEM

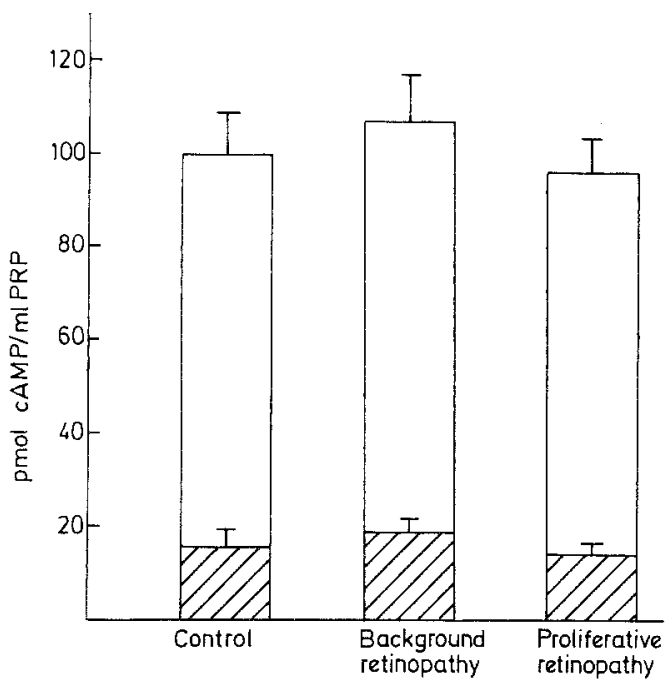

Fig. 1. Basal platelet cAMP levels and cAMP levels after exposure to prostaglandin $\mathrm{E}_{1}\left(\mathrm{PGE}_{1}\right)$ in control and diabetic retinopathy groups. Results given as mean \pm SEM. $n=12$ in all groups. Bast level of cAMP; $\square$ cAMP level after exposure to prostaglandin $\mathrm{E}_{1}$. $\mathrm{PRP}=$ platelet rich plasma

ratio when compared with the other two groups $(p<$ 0.005 ). In the presence of Froben no difference was found between the three groups. (Table 2)

5-Hydroxytryptamine release in response to both collagen and 11,9-em $\mathrm{PGH}_{2}$ showed no difference between the three groups (Table 3 ).

There was no difference in the basal levels of cAMP found in platelets from the three groups or in the rise in cAMP induced by $\mathrm{PGE}_{1}$ (Fig. 1).

\section{Discussion}

This study demonstrated that platelets from Type 1 diabetic patients with proliferative retinopathy are more sensitive to 11,9 -em $\mathrm{PGH}_{2}$ than platelets from Type 1 diabetic patients with background retinopathy and control subjects. However, unlike previous studies in diabetic patients $[15,26-28]$, we did not find increased platelet sensitivity to collagen, whether sensitivity was measured as platelet aggregation or as 5-hydroxytryptamine release. In non-diabetic subjects endogenous
$\mathrm{PGH}_{2}$ and $\mathrm{TXA}_{2}$ production are the major components of collagen-induced aggregation [29]. The aggregation $\mathrm{EC}_{50}$ for collagen was similar for the two diabetic and control groups, with the reversible thromboxane antagonist EP 092 producing a similar shift of the aggregation wave in each group. The cyclooxygenase inhibitor Froben appeared to be slightly less effective in the proliferative group than in the background retinopathy and control groups, but this did not achieve statistical significance. The slight decrease in the efficacy of Froben in this group is consistent with increased thromboxane synthesis in response to collagen without alteration in the aggregation $\mathrm{EC}_{50}$ level. From these observations it would appear that the mechanism for collagen-induced aggregation is similar in both diabetic patients and control subjects.

Age is an important determinant of platelet function in both non-diabetic subjects and diabetic patients [5]. During recruitment to our study we paid particular attention to careful age restriction and comparability. This may account for the apparent discrepancy in platelet collagen sensitivity in diabetic patients in this study compared with other studies [15, 26-28].

In contrast, platelets from the diabetic group with proliferative retinopathy were more responsive to the thromboxane mimetic $11,9-\mathrm{em} \mathrm{PGH}_{2}$. This increase in sensitivity was reduced in the presence of the cyclooxygenase inhibitor, Froben. In non-diabetic subjects the major mechanism of the action of the mimetic does not involve activation of the thromboxane generating system [16, 17]. It would appear, therefore, that the increased sensitivity is not a direct effect of the 11,9-em $\mathrm{PGH}_{2}$ on the receptor. The mechanism of increased sensitivity in the proliferative retinopathy group remains undefined; however, it may be due to increased endogenous thromboxane production during secondary aggregation.

There was no difference between either the basal level of platelet cAMP levels or the increased cAMP level after exposure to $\mathrm{PGE}_{1}$ between diabetic patients and control subjects. This is in agreement with a recent study of $\mathrm{PGI}_{1}$ binding to platelets [31] and activation of adenylate cyclase, but in sharp contrast to that of Lagarde et al. [32], where lower resting levels of cAMP and a diminished response to inhibiting prostaglandins were 
reported. The likely explanation is that in our study and that by Shepherd et al. [31] the subjects were young and age-matched, whereas in the report by Lagarde et al. [32] the ranges of age, duration of diabetes and vascular complications were very wide.

In conclusion, platelets from young Type 1 diabetic patients with microvascular disease in the form of background and proliferative retinopathy are similar to platelets from normal subjects in their response to collagen-induced aggregation. In contrast, platelets from diabetic patients with proliferative retinopathy demonstrate increased sensitivity to a thromboxane mimetic; this may be a factor in the development of proliferative retinopathy.

Acknowledgement. We are grateful to Ms. L. McDonald for typing the manuscript and Dr. R. J. Prescott of the Medical Computing and Statistics Unit, University of Edinburgh, for statistical advice.

\section{References}

1. Colwell JA, Winocour PD, Halushka PV (1983) Do platelets have anything to do with diabetic microvascular disease. Diabetes 32 (Suppl 2): 14-19

2. Betteridge DJ, El Tahir KEH, Reckless JPD, Williams KI (1982) Platelets from diabetic subjects show diminished sensitivity to prostaglandins. Eur J Clin Invest 12: 395-398

3. Schernthaner $G$, Sinzinger $H$, Silberbauer $K$, Freyler $H$, Mühlhauser I, Kaliman J (1981) Vascular prostacyclin, platelet sensitivity to prostaglandins and platelet-specific proteins in diabetes mellitus. Horm Metab Res Suppl 11: 33-43

4. Peterson CM, Jones RL, Koenig RJ, Melvin ET, Lehrman ML (1977) Reversible haematologic sequelae of diabetes mellitus. Ann In Med 86: 425-429

5. Leccrubier C, Scarabin PY, Grauso F, Samama M (1980) Platelet aggregation related to age in diabetes mellitus. Haemostasis 9: 43-48

6. Khosla PK, Mahabaleswara M, Tiwari HK, Saraya AK (1979) Platelet aggregation and retinal microangiopathy in diabetes and hypertension. Acta Haematol 61: 161 167

7. Colwell JA, Sagel J, Crook L, Chambers A, Laimins M (1977) Correlation of platelet aggregation, plasma factor activity, and megathrombocytes in diabetic subjects with and without vascular disease. Metabolism 26: 279-285

8. Stuart MJ, Gerrard JM, White MG (1980) Effect of cholesterol on production of thromboxane $\mathrm{B}_{2}$ by platelets in vitro. $\mathrm{N}$ Engl $\mathrm{J}$ Med 302: 6-10

9. Cederholm-Williams SA, Dornan TL, Turner RC (1981) The metabolism of fibrinogen and plasminogen related to diabetic retinopathy in man. Eur J Clin Invest 11: 133-138

10. Lamberton RP, Goodman AD, Kassof A, Rubin CL, Treble DH, Saba TM, Merimee TJ, Doods WJ (1984) Von Willebrand factor (VIII R: Ag), fibronectin and insulinlike growth factors I and II in diabetic retinopathy and nephropathy. Diabetes 33:125-129

11. Petersen MD, Gormsen J (1978) Platelet aggregation in diabetes mellitus. Acta Med Scand 203: 125-130

12. Davis JW, Phillips PE, Yue KTN, Lewis HD, Hartman CR (1978) Platelet aggregation, adult onset diabetes mellitus and coronary artery disease. J Am Med Assoc 239: 732-734

13. Buktus A, Skrinski VA, Schumacher OP (1980) Thromboxane production and platelet aggregation in diabetic subjects with clinical complications. Thromb Res 19:211-213
14. Halushka PV, Rodgers RC, Loadholt CB, Colwell JA (1981) Increased platelet thromboxane synthesis in diabetes mellitus. J Lab Clin Med 97: 87-96

15. Silberbauer K, Schernthaner G, Sinzinger H, Freyler H (1981) Platelet aggregation and reversible platelet aggregates in type 1 diabetes staged by retinal fluoroscein angiography. Atherosclerosis $40: 81-83$

16. Hamberg M, Svensson J, Samuelsson B (1975) Thromboxanes: A new group of biologically active compounds derived from prostaglandin endoperoxides. Proc Natl Acad Sci USA 72: 2994-2998

17. Moncada S, Vane JR (1978) Pharmacology and endogenous role of prostaglandin endoperoxides, thromboxane $\mathrm{A}_{2}$ and prostaglandin. Pharmacol Rev 30: 293-331

18. Di Minno G, Bertele V, Bianchi L, Barbieri B, Cerletti C, Dejana E, de Gaetano G, Silver MJ (1981) Effects of epoxymethano stable analogue of prostaglandin endoperoxides (U-46619) on human platelets. Thromb Haemost 45: 103

19. Di Minno G, Silver MJ, Cerbone AM, Riccardi G, Rivellese A, Mancini M, Thiagarajan P (1985) Increased binding of fibrinogen to platelets in diabetes: the rate of prostaglandins and thromboxane. Blood 65: 156-162

20. Jones RL, Peesapati V, Wilson NH (1982) Antagonism of the thromboxane-sensitive contractile systems of the rabbit aorta, dog saphenous vein and guinea-pig trachea. $\mathrm{Br} \mathrm{J}$ Pharmacol 76: $423-438$

21. Born GVR (1962) Aggregation of blood platelets by adenosine diphosphate and its reversal. Nature 194: 927-929

22. Armstrong RA, Jones RL, Peespati V, Will SG, Wilson NH (1985) Competitive antagonism of thromboxane receptors in human platelets. Br J Pharmacol 84: 595-607

23. Gilman AG (1970) A protein binding assay for adenosine $3^{\prime}: 5^{\prime}$-cyclic monophosphate. Proc Natl Acad Sci 67: 305-312

24. Read A, Tibi L, Smith AF (1980) Assessment of a simple method for measuring $\mathrm{HbA}_{1}$. Clin Chem Acta 108: 487-491

25. Wilson NH, Peespati V, Jones RL, Hamilton K (1982) Synthesis of prostanoids with bicyclo (2.2.1) heptane, bicyclo (3.3.1) heptane and bicyclo (2.2.2) octane ring systems. Activities of 15 hydroxy epimers on human platelets. J Med Chem 25: 495-500

26. Sagel J, Colwell JA, Crook L, Laimins M (1975) Increased platelet aggregation in early diabetes mellitus. Ann Int Med 82: 733-738

27. Jones RJ, Delamonthe AP, Curtis LD, Machin SJ, Betteridge DJ (1985) Measurement of platelet aggregation in diabetes using the new electronic platelet aggregometer. Diabetes Medicine 2: 105-109

28. Janka HU, Demmel P (1981) Influence of metabolic control on platelet function in diabetes mellitus. Horm Metab Research Suppl 11:29-33

29. Vergaftig BB, Chignard M, Benveniste J (1981) Present concepts on the mechanisms of platelet aggregation. Biochem Pharmacol 30: $263-271$

30. Betteridge DJ, Jahavi J, Jones NAG, Shine B, Kakkar VV, Galton DJ (1981) Platelet function in diabetes mellitus in relationship to complications, glycosylated haemoglobin and serum lipoproteins. Eur J Clin Invest 11: 273-277

31. Shepherd GL, Lewis PJ, Blair IA, De May C, Macdermott J (1983) Epoprostenolol $\left(\mathrm{PGI}_{2}\right)$ binding and activation of adenylate cyclase in platelets of diabetic and control subjects. Br J Clin Pharmacol 15: 77-81

32. Lagarde M, Berciand P, Burton M, Dechavanne M (1981) Refractoriness of diabetic platelets inhibiting prostaglandins. Prostaglandins Med 7:341-347

Received: 17 December 1985

and in revised form: 12 May 1986

Dr. A. Collier

Diabetic and Dietetic Department

The Royal Infirmary

Edinburgh EH3 9YW, UK 